\title{
Efficient whole cell biocatalyst for formate-based hydrogen production
}

\author{
Patrick Kottenhahn, Kai Schuchmann and Volker Müller*
}

\begin{abstract}
Background: Molecular hydrogen $\left(\mathrm{H}_{2}\right)$ is an attractive future energy carrier to replace fossil fuels. Biologically and sustainably produced $\mathrm{H}_{2}$ could contribute significantly to the future energy mix. However, biological $\mathrm{H}_{2}$ production methods are faced with multiple barriers including substrate cost, low production rates, and low yields. The C1 compound formate is a promising substrate for biological $\mathrm{H}_{2}$ production, as it can be produced itself from various sources including electrochemical reduction of $\mathrm{CO}_{2}$ or from synthesis gas. Many microbes that can produce $\mathrm{H}_{2}$ from formate have been isolated; however, in most cases $\mathrm{H}_{2}$ production rates cannot compete with other $\mathrm{H}_{2}$ production methods.

Results: We established a formate-based $\mathrm{H}_{2}$ production method utilizing the acetogenic bacterium Acetobacterium woodii. This organism can use formate as sole energy and carbon source and possesses a novel enzyme complex, the hydrogen-dependent $\mathrm{CO}_{2}$ reductase that catalyzes oxidation of formate to $\mathrm{H}_{2}$ and $\mathrm{CO}_{2}$. Cell suspensions reached specific formate-dependent $\mathrm{H}_{2}$ production rates of $71 \mathrm{mmol} \mathrm{g}_{\text {protein }}^{-1} \mathrm{~h}^{-1}\left(30.5 \mathrm{mmol} \mathrm{g}_{\mathrm{CDW}}^{-1} \mathrm{~h}^{-1}\right)$ and maximum volumetric $\mathrm{H}_{2}$ evolution rates of $79 \mathrm{mmol} \mathrm{L}^{-1} \mathrm{~h}^{-1}$. Using growing cells in a two-step closed batch fermentation, specific $\mathrm{H}_{2}$ production rates reached $66 \mathrm{mmol} \mathrm{g}_{\mathrm{CDW}}^{-1} \mathrm{~h}^{-1}$ with a volumetric $\mathrm{H}_{2}$ evolution rate of $7.9 \mathrm{mmol} \mathrm{L}^{-1} \mathrm{~h}^{-1}$. Acetate was the major side product that decreased the $\mathrm{H}_{2}$ yield. We demonstrate that inhibition of the energy metabolism by addition of a sodium ionophore is suitable to completely abolish acetate formation. Under these conditions, yields up to $1 \mathrm{~mol}$ $\mathrm{H}_{2}$ per mol formate were achieved. The same ionophore can be used in cultures utilizing formate as specific switch from a growing phase to a $\mathrm{H}_{2}$ production phase.

Conclusions: Acetobacterium woodii reached one of the highest formate-dependent specific $\mathrm{H}_{2}$ productivity rates at ambient temperatures reported so far for an organism without genetic modification and converted the substrate exclusively to $\mathrm{H}_{2}$. This makes this organism a very promising candidate for sustainable $\mathrm{H}_{2}$ production and, because of the reversibility of the $A$. woodii enzyme, also a candidate for reversible $\mathrm{H}_{2}$ storage.
\end{abstract}

Keywords: Hydrogen production, Biohydrogen, Acetobacterium woodii, Formate dehydrogenase, Hydrogenase

\section{Background}

Fossil fuel limitation and increasing atmospheric $\mathrm{CO}_{2}$ concentrations necessitate alternative energy carriers. Molecular hydrogen $\left(\mathrm{H}_{2}\right)$ is an attractive carbon-free alternative that can be converted to energy without $\mathrm{CO}_{2}$ emission. It can be used as energy carrier for mobile applications (i.e., fuel cell powered vehicles) or as an intermediate energy storage system to store excess electrical energy that is produced in peak times from

*Correspondence: vmueller@bio.uni-frankfurt.de

Molecular Microbiology \& Bioenergetics, Institute of Molecular

Biosciences, Johann Wolfgang Goethe University, Max-von-Laue-Str. 9, 60439 Frankfurt am Main, Germany renewable sources [1]. Currently, $\mathrm{H}_{2}$ is produced mainly from fossil fuels by steam reforming and thus unsustainable and environmentally harmful [2]. Hence, new $\mathrm{H}_{2}$ production methods are required.

Biologically produced $\mathrm{H}_{2}$ provides a promising alternative for a sustainable $\mathrm{H}_{2}$-based energy economy. $\mathrm{H}_{2}$ production by biological systems can generally be classified into four different mechanisms: direct and indirect biophotolysis, photofermentation, and dark fermentation [3]. From these processes, the latter mechanism has so far the highest $\mathrm{H}_{2}$ evolution rates (HER). However, the major drawback of dark fermentations, e.g., from glucose, is the low $\mathrm{H}_{2}$ yield per substrate consumed and the limitations of agricultural production of the substrate [4]. A 
recently considered alternative substrate is formic acid/ formate that could be produced from electrochemical reduction of $\mathrm{CO}_{2}$ or from synthesis gas, a very flexible substrate that can derive as by-product from steel mills or from waste gasification [5-7]. Conversion of formate to $\mathrm{H}_{2}$ proceeds according to the reaction:

$$
\mathrm{HCOO}^{-}+\mathrm{H}_{2} \mathrm{O} \rightleftharpoons \mathrm{HCO}_{3}^{-}+\mathrm{H}_{2} \quad \Delta G^{0^{\prime}}=+1.3 \mathrm{~kJ} \mathrm{~mol}^{-1} .
$$

Microbial formate oxidation is catalyzed by multiple enzyme systems. Organisms such as some enterobacteria use a membrane-bound formate-hydrogen lyase system composed of membrane-associated hydrogenase and formate dehydrogenase subunits [8,9]. Clostridiaceae or archaea such as Methanococcus can produce $\mathrm{H}_{2}$ from formate by the action of separate cytoplasmic formate dehydrogenases and hydrogenases [10]. The observed HERs for these organisms are typically very low and do not reach the levels for $\mathrm{H}_{2}$ production from other feedstocks [4]. One exception is the recently characterized organism Thermococcus onnurineus. This organism requires $80{ }^{\circ} \mathrm{C}$ for growth and formate-dependent $\mathrm{H}_{2}$ formation reached HERs that outcompete other dark fermentations for the first time $[11,12] . \mathrm{H}_{2}$ production in this organism depends on a membrane-bound enzyme complex of formate dehydrogenase, hydrogenase, and $\mathrm{Na}^{+} / \mathrm{H}^{+}$antiporter subunits that couples $\mathrm{H}_{2}$ formation to formate oxidation as well as energy conservation $[13,14]$.

A new enzyme of the bacterial formate metabolism has been discovered recently in the strictly anaerobic bacterium Acetobacterium woodii [15]. The enzyme named hydrogen-dependent $\mathrm{CO}_{2}$ reductase (HDCR) was the first described soluble enzyme complex that reversibly catalyzes the reduction of $\mathrm{CO}_{2}$ to formate with $\mathrm{H}_{2}$ as electron donor. $\mathrm{CO}_{2}$ reduction is catalyzed at ambient conditions with rates far superior to chemical catalysis [15-17]. Therefore, it could not only be used for $\mathrm{H}_{2}$ production but, depending on the application, for $\mathrm{H}_{2}$ storage as well. In the form of formate, the explosive gas could be stored and handled much easier and with an increased volumetric energy density [18]. $\mathrm{H}_{2}$-dependent $\mathrm{CO}_{2}$ reduction to formate by the HDCR has also been shown to be very efficient in whole cell catalysis with $A$. woodii [15]. However, the reverse reaction has not been addressed in detail so far.

In the present report, we describe the first characterization of formate-based $\mathrm{H}_{2}$ production with an organism harboring an HDCR complex. The results show that $A$. woodii has $\mathrm{H}_{2}$ production rates from formate of $66 \mathrm{mmol}$ $\mathrm{H}_{2} \mathrm{~g}_{\mathrm{CDW}}^{-1} \mathrm{~h}^{-1}$ at ambient temperatures that are among the highest reported so far for an organism without genetic modification. Therefore, $A$. woodii is an efficient catalyst for $\mathrm{H}_{2}$ production and, considering the reversibility of the whole cell system, a potent catalyst for reversible $\mathrm{H}_{2}$ storage. In addition, $A$. woodii can grow with formate as sole carbon and energy source making it possible to produce cell mass and $\mathrm{H}_{2}$ with the same substrate.

\section{Results}

\section{$\mathrm{H}_{2}$ production with resting cells}

The acetogenic bacterium $A$. woodii can utilize, among others, $\mathrm{H}_{2}+\mathrm{CO}_{2}$, formate, or monosaccharides such as fructose as substrates for growth. In all three cases, acetate (or acetate $+\mathrm{CO}_{2}$ in the case of formate) is the major end product $[19,20]$. Recently, we could show that the addition of the sodium ionophore ETH2120 (sodium ionophore III) led to a complete inhibition of acetate formation from $\mathrm{H}_{2}+\mathrm{CO}_{2}$ and the two gases were completely converted to formate [15]. This opened the possibility to utilize $A$. woodii as catalyst for $\mathrm{H}_{2}$ storage. The hydrogen-dependent $\mathrm{CO}_{2}$ reduction activity could be addressed to a novel enzyme complex of a formate dehydrogenase and hydrogenase, named HDCR. Experiments with the purified enzyme showed that the catalyzed reaction proceeds with almost the same rate in the reverse reaction as well, making $A$. woodii a potential candidate for formate-based $\mathrm{H}_{2}$ production [15]. In this study, we analyzed this potential using whole cells of $A$. woodii. First, we grew the organism with fructose, a substrate to reach high cell densities relatively quickly (doubling time $t_{\mathrm{D}}=4.7 \mathrm{~h}$ compared to $11 \mathrm{~h}$ with formate as substrate), harvested the cells, and incubated them in reaction buffer at a protein concentration of $1 \mathrm{mg} \mathrm{mL} L^{-1}$ (corresponding to $2.3 \mathrm{mg}_{\mathrm{CDW}} \mathrm{mL}^{-1}$ ). After addition of sodium formate to a final concentration of $300 \mathrm{mM}$, the cells produced $\mathrm{H}_{2}$ with an initial specific $\mathrm{H}_{2}$ productivity $\left(\mathrm{qH}_{2}\right)$ of $52.2 \pm 3 \mathrm{mmol} \mathrm{g}_{\text {protein }}^{-1} \mathrm{~h}^{-1}\left(22.5 \mathrm{mmol} \mathrm{g}_{\mathrm{CDW}}^{-1} \mathrm{~h}^{-1}\right)$ (Fig. 1). $0.6 \mathrm{mmol} \mathrm{H}_{2}$ was produced from $2.14 \mathrm{mmol}$ formate consumed leading to a yield of $\mathrm{H}_{2}$ consumed per substrate consumed $\left(Y_{\left(\mathrm{H}_{2} / \text { formate }\right)}\right)$ of $0.28 \mathrm{~mol} \mathrm{~mol}^{-1}$. It was surprising to observe these high $\mathrm{H}_{2}$ production rates since $\mathrm{H}_{2}$ is typically no major product from cells growing on formate; however, $Y_{\left(\mathrm{H}_{2} / \text { formate) }\right.}$ was significantly decreased by the high amount of $0.45 \mathrm{mmol}$ acetate produced alongside $\mathrm{H}_{2}$. The produced acetate results from the assimilation of $\mathrm{CO}_{2}$ or formate via the WoodLjungdahl pathway for autotrophic $\mathrm{CO}_{2}$ fixation of $A$. woodii $[20,21]$. As shown recently for the reverse reaction of formate formation from $\mathrm{H}_{2}+\mathrm{CO}_{2}$, we tried to decrease acetate formation by addition of the sodium ionophore ETH2120. Acetate formation in A. woodii is coupled to a sodium ion gradient for energy conservation across the cytoplasmic membrane that can be specifically diminished by the sodium ionophore. In the presence of $30 \mu \mathrm{M}$ ETH2120, the final amount of $\mathrm{H}_{2}$ produced increased to $1.15 \mathrm{mmol}$ from $1.68 \mathrm{mmol}$ 


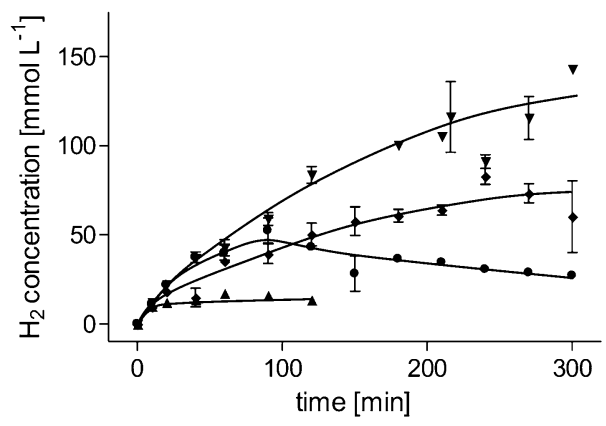

Fig. $1 \mathrm{H}_{2}$ production from formate by resting cells of $A$. woodii. Cells were grown with $20 \mathrm{mM}$ fructose, harvested in the exponential growth phase, and suspended in buffer $(50 \mathrm{mM}$ imidazole, $20 \mathrm{mM}$ $\mathrm{KCl}, 20 \mathrm{mM} \mathrm{MgSO}_{4}, 4 \mathrm{mM}$ DTE, $\mathrm{pH}$ 7) to a final protein concentration of $1 \mathrm{mg} \mathrm{mL}^{-1}$ (corresponding to a CDW of $2.3 \mathrm{~g} \mathrm{~L}^{-1}$ ) in anoxic serum bottles (gas phase $100 \% \mathrm{~N}_{2}$ ). The bottles were incubated in a shaking water bath at $30^{\circ} \mathrm{C}$. At the beginning of the experiment, sodium formate, potassium formate, ETH2120, NaCl, and ethanol (solvent of ETH2120 as negative control) were added as indicated. Triangles down, 300 mM sodium formate, 30 MM ETH2120 (dissolved in 100\% ethanol), $20 \mathrm{mM} \mathrm{NaCl}$; diamonds, $300 \mathrm{mM}$ sodium formate, $20.5 \mathrm{mM}$ ethanol, $20 \mathrm{mM} \mathrm{NaCl}$; circles, $100 \mathrm{mM}$ K-formate; triangles up, $100 \mathrm{mM}$ sodium formate, $20.5 \mathrm{mM}$ ethanol, $20 \mathrm{mM} \mathrm{NaCl}$

formate consumed. At the same time, acetate formation decreased to a final amount of $0.17 \mathrm{mmol}$ acetate. In summary, addition of ETH2120 increased $Y_{\left(\mathrm{H}_{2} / \text { formate }\right)}$ to $0.68 \mathrm{~mol} \mathrm{~mol}^{-1}$. An alternative approach to the inhibition of acetate formation by ETH2120 is the depletion of the cells for sodium ions. In the $\mathrm{CO}_{2}$ reduction direction, sodium ion depletion showed the same effect on formate formation as ETH2120 but comes with much less cost for the fermentation. To test this for $\mathrm{H}_{2}$ production, we added potassium formate instead of sodium formate. Initial $\mathrm{qH}_{2}$ was identical to ETH2120 inhibited cells and the amount of $\mathrm{H}_{2}$ produced was more than double compared to the control (Fig. 1). However, after $100 \mathrm{~min}$ we observed reassimilation of $\mathrm{H}_{2}$ which decreased the product significantly. We interpret this result as an incomplete inhibition of sodium-dependent acetate formation due to sodium ion contamination in the potassium formate, which is $0.5 \%$ in $\geq 99.0 \%$ potassium formate used.

In the initial experiments, we used fructose-grown cells as catalysts. An advantage of $A$. woodii is the wide range of possible growth substrates. Depending on the process and available substrate, cultivation of the cells on $\mathrm{H}_{2}+\mathrm{CO}_{2}$ or directly on formate might be advantageous. $\mathrm{qH}_{2}$ in cells grown on $\mathrm{H}_{2}+\mathrm{CO}_{2}$ was almost identical to formate-grown cells; however, with $21 \mathrm{mmol} \mathrm{g}_{\text {protein }}^{-1} \mathrm{~h}^{-1}$ only $67 \%$ of the $\mathrm{qH}_{2}$ of fructosegrown cells was reached (Fig. 2a). $\mathrm{pH}$ dependency showed a decrease in $\mathrm{qH}_{2}$ with increasing $\mathrm{pH}$ within the tested $\mathrm{pH}$ range of $6-9$ (Fig. 2b). Highest $\mathrm{qH}_{2}$ was observed at a $\mathrm{pH}$ of 6 with $37 \mathrm{mmol} \mathrm{g}_{\text {protein }}^{-1} \mathrm{~h}^{-1}$. When using increasing cell densities, we observed a linear increase in HERs up to $79 \mathrm{mmol} \mathrm{L}^{-1} \mathrm{~h}^{-1}$ but a decrease in $\mathrm{qH}_{2}$ (Fig. 3). Maximum specific $\mathrm{H}_{2}$ production of $71 \mathrm{mmol} \mathrm{g}_{\text {protein }}^{-1} \mathrm{~h}^{-1}\left(30.5 \mathrm{mmol} \mathrm{g}_{\mathrm{CDW}}^{-1} \mathrm{~h}^{-1}\right)$ was observed at a protein concentration of $0.5 \mathrm{mg} \mathrm{mL}^{-1}$. At the same time, increasing cell densities led to higher accumulation of acetate and less production of $\mathrm{H}_{2}$, meaning that ETH2120 inhibition decreases at higher cell densities. In the next experiment, we tested inhibition of $\mathrm{H}_{2}$ production by increased formate concentrations. We tested formate concentrations from 25 to $600 \mathrm{mM}$. Within this range, initial $\mathrm{H}_{2}$ production rates did not change, with similar HERs up to $600 \mathrm{mM}$
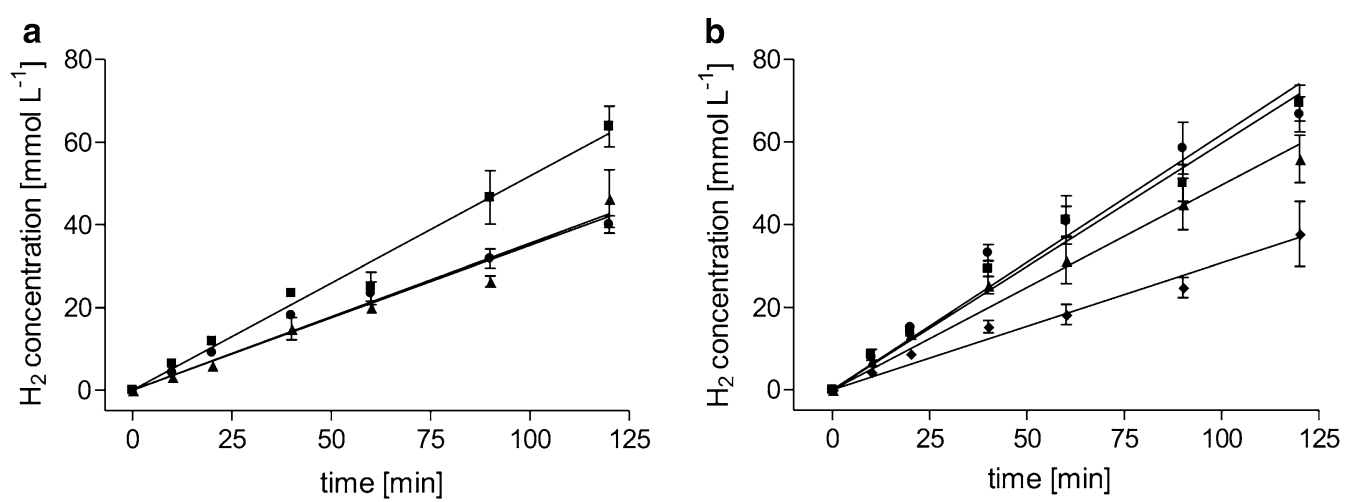

Fig. 2 Influence of the growth substrate (a) and pH (b) on $\mathrm{H}_{2}$ production. a Cells were grown with $20 \mathrm{mM}$ fructose (squares), 2 atm. $\mathrm{H}_{2}+\mathrm{CO}_{2}$ (80:20 [v:v], triangles), or $100 \mathrm{mM}$ sodium formate (circles). The experiment was performed as described for Fig. 1 using $300 \mathrm{mM}$ sodium formate, $30 \mu \mathrm{M}$ ETH2120, and $20 \mathrm{mM} \mathrm{NaCl}$. b Fructose-grown cells were suspended in buffer ( $25 \mathrm{mM} \mathrm{MES}, 25 \mathrm{mM}$ Tris, 25 mM MOPS, 25 mM CHES, 20 mM $\mathrm{KCl}, 20 \mathrm{mM} \mathrm{MgSO}_{4}, 4 \mathrm{mM}$ DTE, $20 \mathrm{mM} \mathrm{NaCl}$ ) at pH 6 (circles), $\mathrm{pH} 7$ (squares), pH 8 (triangles), $\mathrm{pH} 9$ (diamonds). The experiment was started by the addition of sodium formate to a final concentration of $300 \mathrm{mM}$ 


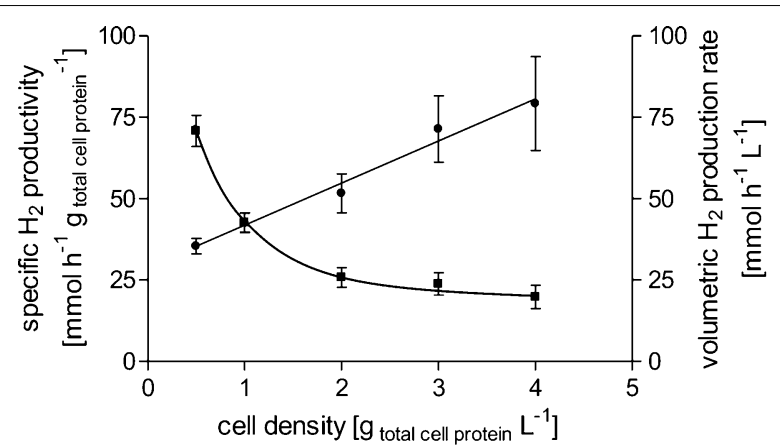

Fig. 3 Influence of the cell density on volumetric and specific $\mathrm{H}_{2}$ production rates. Cells were grown with $20 \mathrm{mM}$ fructose, harvested in the exponential growth phase, and suspended in buffer $(50 \mathrm{mM}$ imidazole, $20 \mathrm{mM} \mathrm{KCl}, 20 \mathrm{mM} \mathrm{MgSO}_{4}, 30 \mu \mathrm{M} \mathrm{ETH2120,20} \mathrm{mM} \mathrm{NaCl}$, $4 \mathrm{mM}$ DTE, $\mathrm{pH}$ 7) to a final protein concentration of $0.5-4 \mathrm{mg} \mathrm{mL}^{-1}$ (corresponding to a CDW of 1.2-9.7 $\mathrm{g} \mathrm{L}^{-1}$ ). Experiments were started by the addition of $100 \mathrm{mM}$ sodium formate. Initial specific $\mathrm{H}_{2}$ production rates (squares) or initial volumetric $\mathrm{H}_{2}$ production rates (circles) are plotted against the cell density used

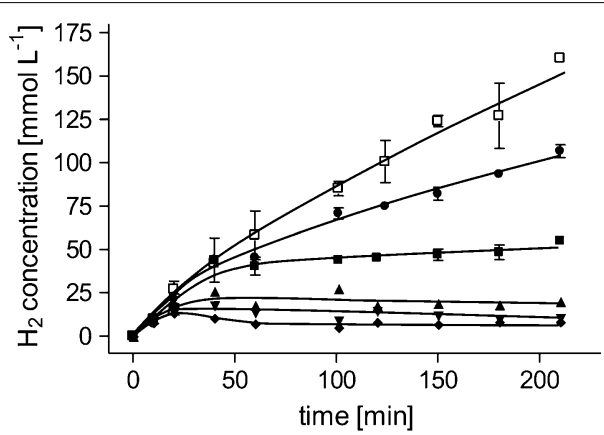

Fig. 4 Influence of the formate concentration on $\mathrm{H}_{2}$ production. Cells were grown with $20 \mathrm{mM}$ fructose, harvested in the exponential growth phase, and suspended in buffer ( $50 \mathrm{mM}$ imidazole, $20 \mathrm{mM}$ $\mathrm{KCl}, 20 \mathrm{mM} \mathrm{MgSO}_{4}, 30 \mu \mathrm{M} \mathrm{ETH2120,20} \mathrm{mM} \mathrm{NaCl}, 4 \mathrm{mM} \mathrm{DTE}, \mathrm{pH}$ 7) to a final protein concentration of $1 \mathrm{mg} \mathrm{mL}^{-1}$ (corresponding to a CDW of $2.3 \mathrm{~g} \mathrm{~L}^{-1}$ ). Experiments were started by the addition of $25 \mathrm{mM}$ (diamonds), $50 \mathrm{mM}$ (triangles down), $100 \mathrm{mM}$ (triangles up), $200 \mathrm{mM}$ (closed squares), $400 \mathrm{mM}$ (circles), $600 \mathrm{mM}$ formate (open squares)

sodium formate tested, demonstrating that formate is not inhibiting the catalyst even at high concentrations. Final $\mathrm{H}_{2}$ concentrations increased with increasing initial formate concentrations (Fig. 4).

\section{$\mathrm{H}_{2}$ production in batch fermentation}

The experiments described with resting cells showed that A. woodii is a promising catalyst for formate-dependent $\mathrm{H}_{2}$ production at ambient temperatures. For these experiments, cells were grown, harvested under anoxic conditions, and incubated in anoxic reaction buffer. This procedure is labor-intensive and requires sophisticated techniques to maintain anoxic conditions. To optimize this procedure, we wanted to abolish the medium exchange and establish $\mathrm{H}_{2}$ production directly in closed batch fermentation. Therefore, cells were grown with $20 \mathrm{mM}$ fructose as substrate to mid-exponential growth phase $\left(t_{\mathrm{D}}=4.7 \mathrm{~h}\right)$. At this point, formate was added with or without $30 \mu \mathrm{M}$ ETH2120. Addition of the sodium ionophore led to an immediate growth arrest, whereas addition of formate alone had no effect on the growth rate (data not shown). After addition of formate, $\mathrm{H}_{2}$ was produced with a HER of $7.9 \mathrm{mmol} \mathrm{L}^{-1} \mathrm{~h}^{-1}$ and a $\mathrm{qH}_{2}$ of $65.9 \mathrm{mmol} \mathrm{g}_{\mathrm{CDW}}^{-1} \mathrm{~h}^{-1}$ (Fig. 5a). Without addition of ETH2120, the $\mathrm{H}_{2}$ evolution rate was $4.5 \mathrm{mmol} \mathrm{L}^{-1} \mathrm{~h}^{-1}$ initially, but decreased significantly after $1 \mathrm{~h}$. After addition of formate, acetate was still produced alongside $\mathrm{H}_{2}$ when no ETH2120 was added $\left(78.4 \mathrm{mmol} \mathrm{L}^{-1}\right.$ after $23 \mathrm{~h}$ ) (Fig. 5b). In contrast, cells in the presence of ETH2120 did produce acetate only in marginal amounts as side product $\left(0.3 \mathrm{mmol} \mathrm{L} \mathrm{L}^{-1}\right) . Y_{\left(\mathrm{H}_{2} / \text { formate }\right)}$ was $0.08 \mathrm{~mol}$ $\mathrm{H}_{2}$ mol formate ${ }^{-1}$ without and $1.06 \mathrm{~mol} \mathrm{~mol}^{-1}$ with ETH2120. The $Y_{\left(\mathrm{H}_{2} / \text { formate }\right)}$ above 1 can be explained by some $\mathrm{H}_{2}$ being produced from fructose still present in the fermentation $\left(0.2\right.$ and $1.2 \mathrm{mmol} \mathrm{L}^{-1}$ of $\mathrm{H}_{2}$ where produced with and without ETH2120, respectively, from fructose alone). We observed that without addition of the ionophore, a total amount of $12.1 \mathrm{mmol}$ formate was consumed from the initial $15 \mathrm{mmol}$ (corresponding to a concentration of $300 \mathrm{mM}$ ). In the presence of ETH2120, this value decreased to $4.5 \mathrm{mmol}$. However, this can be explained from the different energetics of the reactions. Conversion of formate to acetate is highly exergonic, whereas conversion of formate to $\mathrm{H}_{2}$ is slightly endergonic, limiting the total conversion of formate in a batch system.

Next, we wanted to further optimize the system by generating cell mass directly from formate as substrate, therefore testing a system independent on carbohydrates and using formate for growth and $\mathrm{H}_{2}$ production. Therefore, $A$. woodii was grown with $100 \mathrm{mM}$ sodium formate $\left(t_{\mathrm{D}}=11 \mathrm{~h}\right)$. These cultures already produced small amounts of $\mathrm{H}_{2}$ during growth (around $2 \mathrm{mmol} \mathrm{L}^{-1}$ before the switch to the production phase). To switch from growth to production phase, $15 \mathrm{mmol}$ additional sodium formate (corresponding to $300 \mathrm{mM}$ in the culture volume of $50 \mathrm{~mL}$ ) with and without ETH2120 were added. As in the case for fructose-grown cells, $\mathrm{H}_{2}$ was produced immediately after addition of ETH2120 with a HER of $1.2 \mathrm{mmol} \mathrm{L}^{-1} \mathrm{~h}^{-1}$ and a specific production rate of $19 \mathrm{mmol} \mathrm{g}_{\mathrm{CDW}}^{-1} \mathrm{~h}^{-1}$. At the end of the fermentation, $25.1 \mathrm{mmol} \mathrm{L} \mathrm{m}^{-1} \mathrm{H}_{2}$ was produced from $36.2 \mathrm{mmol}$ $\mathrm{L}^{-1}$ formate consumed when ETH2120 was added $\left(Y_{\left(\mathrm{H}_{2} / \text { formate }\right)}=0.69 \mathrm{~mol} \mathrm{H}_{2}\right.$ mol formate $\left.{ }^{-1}\right)$ (Fig. 6). Additional acetate was not produced after the addition of 

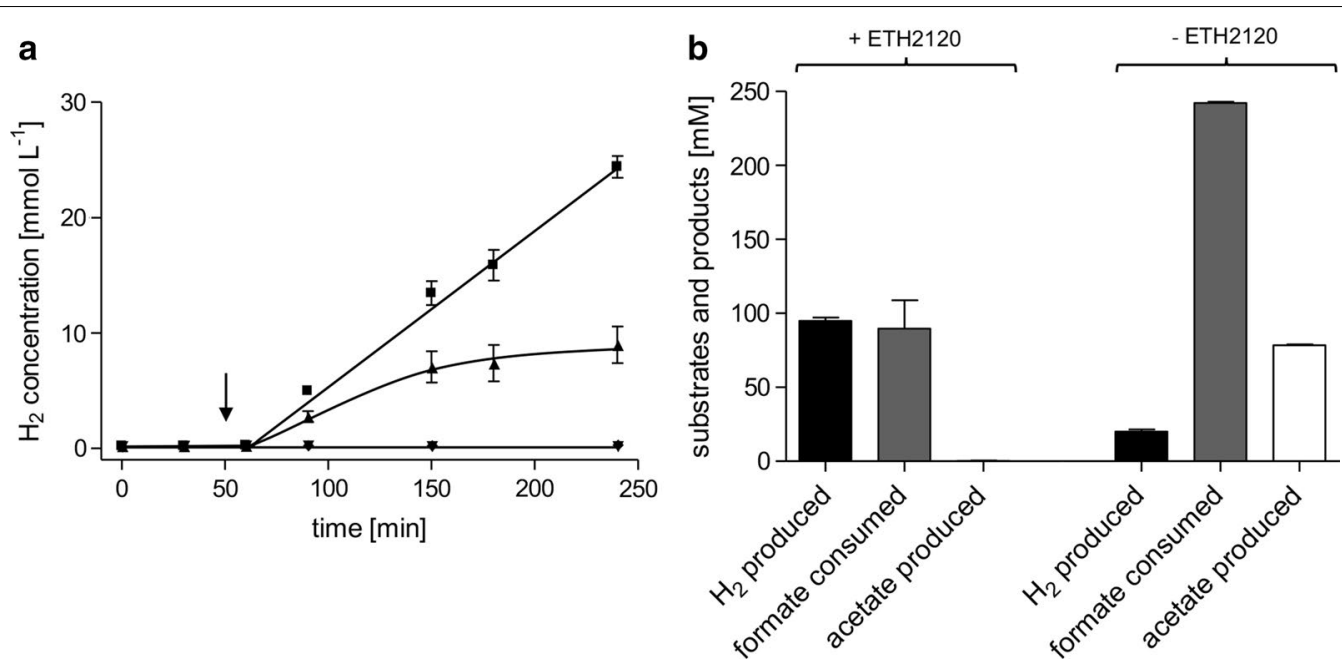

Fig. $5 \mathrm{H}_{2}$ production in closed batch fermentation by fructose-grown cells. A. woodii was grown in $50 \mathrm{~mL}$ carbonate-free growth medium with $20 \mathrm{mM}$ fructose at $30^{\circ} \mathrm{C}$ in a shaking water bath. At the point indicated, production phase was initiated by addition of sodium formate, ETH2120, or ethanol (solvent of ETH2120 as negative control). At this time point, the optical density of all cultures was between 0.35 and 0.45 . $\mathrm{H}_{2}$ was measured in the gas phase and is plotted as $\mathrm{mmol} \mathrm{H}_{2}$ per liter of growth medium (a). Substrate and product balance during the production phase (b) is shown as difference between $t=1 \mathrm{~h}$ (addition of formate and ionophore) and $t=24 \mathrm{~h}$ (end of fermentation). Squares, $300 \mathrm{mM}$ sodium formate,

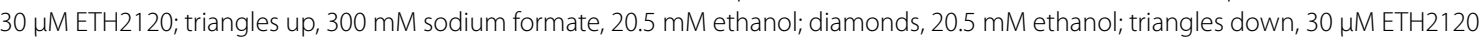

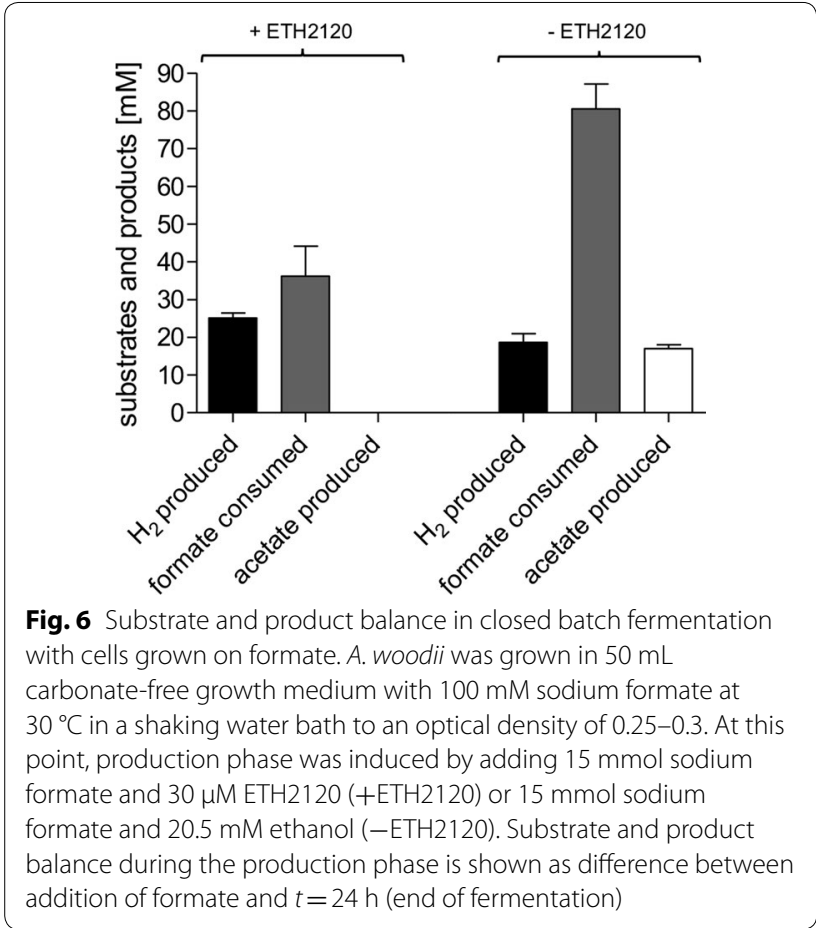

the ionophore. Without ETH2120, $18.6 \mathrm{mmol} \mathrm{L}^{-1} \mathrm{H}_{2}$ and $17.0 \mathrm{mmol} \mathrm{L}{ }^{-1}$ acetate were produced from $80.5 \mathrm{mmol}$ $\mathrm{L}^{-1}$ formate. This results in a lower $Y_{\left(\mathrm{H}_{2} / \text { formate }\right)}$ of $0.23 \mathrm{~mol} \mathrm{H}_{2} \mathrm{~mol}^{-1}$ formate. In comparison to fructosegrown cells, the final amount of $\mathrm{H}_{2}$ produced was much lower, even though the same amounts of formate were supplied. This could be an effect of the conditions established by the cells during the growth phase, e.g., growth on fructose leads to an acidification of the medium, whereas growth on formate increases the pH. Further studies need to address the optimal media composition depending on the substrate used for the growth phase. Nevertheless, the experiments with growing cells demonstrate in each case that the metabolism of $A$. woodii can be specifically switched from growth and acetate formation to $\mathrm{H}_{2}$ production by interfering with the sodium ion gradient across the membrane and thus dramatically increasing the yield coefficient $Y_{\left(\mathrm{H}_{2} / \text { formate) }\right.}$.

\section{Discussion}

In this study, we examined the $\mathrm{H}_{2}$ production capacity of the anaerobic bacterium $A$. woodii. This organism is a promising candidate for formate-based $\mathrm{H}_{2}$ production due to the recently identified reversible hydrogen-dependent $\mathrm{CO}_{2}$ reductase complex (HDCR), an enzyme able to reversibly reduce $\mathrm{CO}_{2}$ to formate with $\mathrm{H}_{2}$ as electron donor with so far exceptional catalysis rates. This enzyme catalyzes the first step in the WoodLjungdahl pathway, the pathway for $\mathrm{CO}_{2}$ fixation and energy conservation in this organism that has a wide substrate spectrum for growth ranging from monosaccharides, mono- and diols, $\mathrm{H}_{2}+\mathrm{CO}_{2}$, and, especially important in this context, formate [20, 22]. However, without modification this organism produces mainly acetate as end product from most substrates [19]. As shown in this study, cells growing on formate produce 
only very little $\mathrm{H}_{2}$. Addition of high concentrations of formate to cells growing on formate or fructose led to immediate $\mathrm{H}_{2}$ production; however, $\mathrm{H}_{2}$ production rapidly slowed down and acetate was still produced. $A$. woodii can use $\mathrm{H}_{2}+\mathrm{CO}_{2}$ for growth and acetate formation, and therefore this result is not unexpected since $\mathrm{H}_{2}+\mathrm{CO}_{2}$ is the product of formate oxidation by the HDCR complex [15] (Fig. 7). The HDCR is not connected to the metabolism by electron carriers such as $\mathrm{NAD}^{+} / \mathrm{NADH}$ and it seems, from the results here, that it catalyzes formate oxidation unregulated if the formate concentration increases suddenly even if this provides no advantage for the cell. The independence of the HDCR from other metabolic processes makes it feasible to inhibit the major pathways for substrate conversion and growth by still retaining HDCR activity. As shown before, a very specific target for inhibiting the metabolism is the sodium ion gradient across the membrane that is built up during acetate formation and is necessary for energy conservation and growth. We assume that formate is imported by the putative formate transporter FdhC2 (Awo_c08050) whose gene is in close proximity to the HDCR gene cluster. FdhC2 could couple formate import to the proton gradient

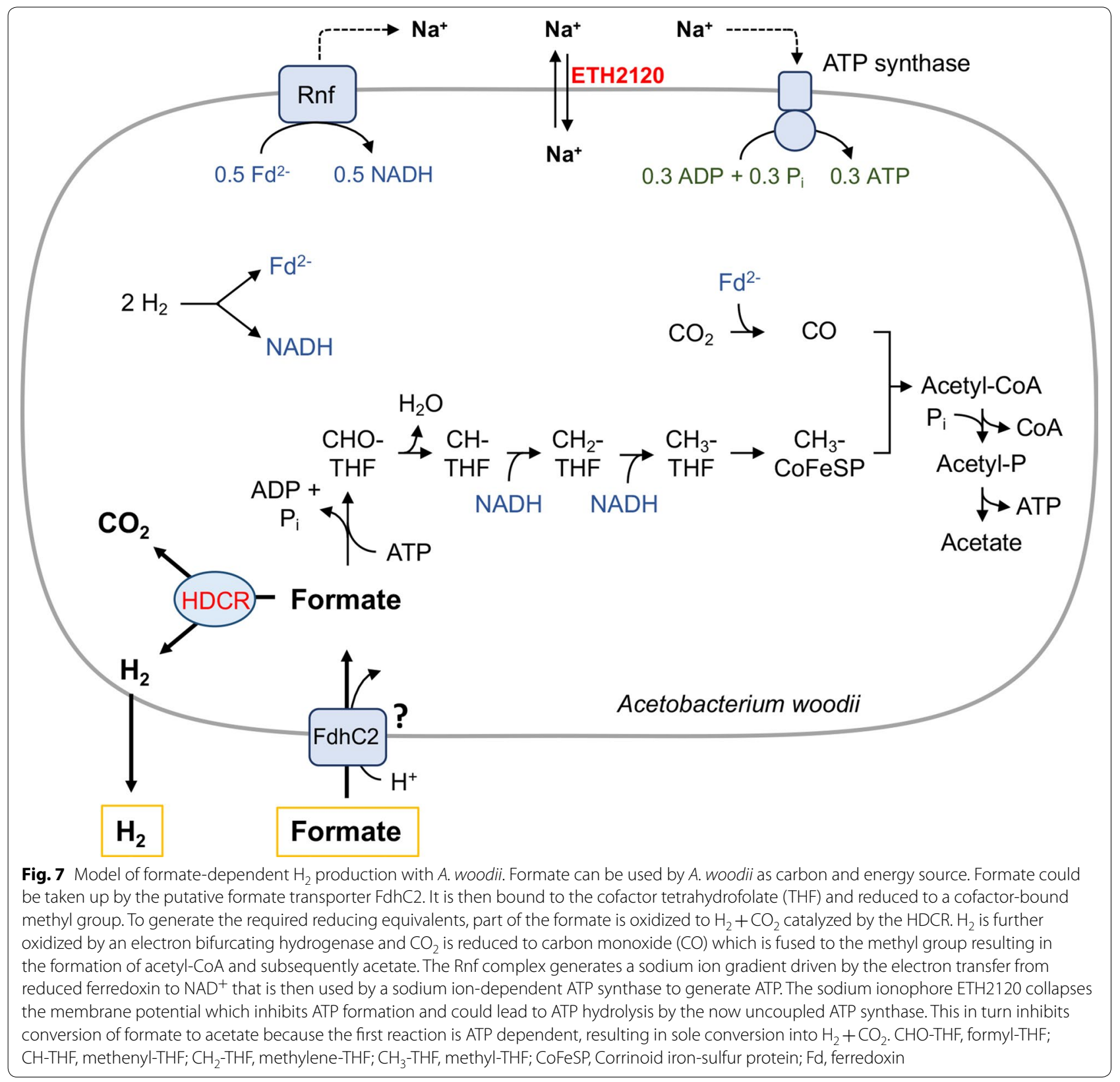


due to the similarity of the primary structure to the formate transporter FocA of Escherichia coli or Salmonella typhimurium [23, 24] (Fig. 7). In the next step, formate is reduced via the Wood-Ljungdahl pathway and the necessary reducing equivalents for this process are generated by oxidizing part of the formate via the HDCR. Addition of the ionophore should inhibit the reductive formate pathway without influencing the HDCR activity. This should stop acetate formation and result in the accumulation of hydrogen. At the same time, collapsing the membrane potential should be advantageous for uptake of the negatively charged formate molecule. As demonstrated in this study, neutralizing this gradient by adding a sodium ionophore (we used ETH2120) proved to be an effective switch from acetate to $\mathrm{H}_{2}$ production if formate is provided as substrate. It was possible to completely turn off acetate and biomass formation and reach yields $\left(Y_{\left(\mathrm{H}_{2} / \text { formate }\right)}\right)$ of $100 \%$. Comparing the total amount of formate consumed with and without ETH2120 showed that formate utilization stopped earlier when cells were inhibited by the ionophore. However, in this case formate was completely converted to $\mathrm{H}_{2}$ and this reaction is slightly endergonic $\left(\Delta G^{0^{\prime}}=+1.3 \mathrm{~kJ} \mathrm{~mol}^{-1}\right)$. The equilibrium constant of this reaction is therefore only 0.6. In the absence of the sodium ionophore, formate is mainly converted to acetate. This reaction is highly exergonic $\left(\Delta G^{0^{\prime}}=-110 \mathrm{~kJ} \mathrm{~mol}^{-1}[25]\right)$ explaining the increased formate consumption. The thermodynamics of formate-based $\mathrm{H}_{2}$ production might seem as a disadvantage; however, the reaction close to the thermodynamic equilibrium allows simple adjustment of the direction of the reaction without additional energy supply. $\mathrm{H}_{2}$ can be produced from formate or stored in the form of formate without the input of much energy, a prerequisite for a reversible $\mathrm{H}_{2}$ storage material. Another very attractive property of formate-based $\mathrm{H}_{2}$ production is the complete conversion of the substrate to gaseous products. The substrate could be continuously supplied to the fermentation in the form of formic acid (at the same time providing a constant $\mathrm{pH}$ ) resulting in the formation of $\mathrm{H}_{2}+\mathrm{CO}_{2}$ only, circumventing any inhibition by dissolved products. Future studies need to address the long-term stability of the ionophore inhibited $A$. woodii system in such a continuous and $\mathrm{pH}$-controlled fermentation. The price of the ionophore ETH2120 is a disadvantage considering the economic feasibility of the process. We used this compound to specifically study the effect of collapsing the membrane potential. However, with the gained knowledge that it is only necessary to inhibit the metabolism at any point it should be possible to identify other more inexpensive inhibitors. Alternatively, with the advent of genetic tools in acetogenic bacteria, mutations could be introduced to block key steps of the metabolism that stops acetate production and keeps the HDCR functional.

In summary, $A$. woodii and the corresponding enzyme HDCR turned out to be a very promising catalyst for formate-based $\mathrm{H}_{2}$ production and storage, as it operates at ambient temperatures with very similar reaction rates in the forward and reverse reaction. The specific $\mathrm{H}_{2}$ productivity $\left(\mathrm{qH}_{2}\right)$ from formate observed with whole cells of $A$. woodii $\left(66 \mathrm{mmol} \mathrm{g}_{\mathrm{CDW}}^{-1} \mathrm{~h}^{-1}\right)$ is among the highest reported at ambient temperatures for an organism without genetic modification, highlighting the $\mathrm{H}_{2}$ production potential of this organism $[4,5]$. Much higher $\mathrm{qH}_{2}$ are reported at $80{ }^{\circ} \mathrm{C}$ utilizing the thermophile $T$. onnurineus [12]. This organism uses a different enzyme system for formate-based $\mathrm{H}_{2}$ production, namely a membrane-bound enzyme complex consisting of a hydrogenase, formate dehydrogenase, and $\mathrm{Na}^{+} / \mathrm{H}^{+}$antiporter subunits [13]. If T. onnurineus can also catalyze, the reverse reaction has not been shown so far. At ambient temperatures, the best results have been achieved using E. coli or other Enterobacteria such as Citrobacter in non-growing conditions [26]. Without genetic modification, E. coli has typically a low formate-dependent $\mathrm{H}_{2}$ productivity. However, by metabolic engineering including overexpression of the formate-hydrogen lyase enzyme, deletion of inhibitory pathways such as uptake hydrogenases and process optimization, the $\mathrm{H}_{2}$ productivity could be increased dramatically $\left(144.2 \mathrm{mmol} \mathrm{g}^{-1} \mathrm{~h}^{-1}\right.$ when products was removed continuously from the medium) [27, 28]. On the other hand, E. coli is inhibited by low concentrations of approximately $50 \mathrm{mM}$ formate. This was addressed by using agar-embedded immobilized cells that were able to tolerate higher concentrations [29].

\section{Conclusions}

This study demonstrated that $A$. woodii is an efficient $\mathrm{H}_{2}$ producer from the very flexible and inexpensive substrate formate. Together with our recent study on the reverse reaction, the results show that $A$. woodii can also be used as whole cell biocatalyst for the reversible storage of $\mathrm{H}_{2}$, by binding it to $\mathrm{CO}_{2}$ to produce formate and vice versa. Future studies need to address the process in a larger scale and in a continuous fermentation to analyze the stability and investigate alternatives to the expensive inhibitor ETH2120. Since any inhibition of the metabolism that does not affect the HDCR should be sufficient, other inhibitors or a genetic modification of the organism should be easy to find to improve the cost of the process. 


\section{Methods}

\section{Growth of $A$. woodii}

Acetobacterium woodii (DSM 1030) was cultivated at $30{ }^{\circ} \mathrm{C}$ under anaerobic conditions. The defined carbonate buffered medium was prepared as described [30]. For closed batch fermentation, defined phosphate buffered medium was used and prepared as described [31]. Fructose $(20 \mathrm{mM})$, formate $(100 \mathrm{mM})$, or $\mathrm{H}_{2}+\mathrm{CO}_{2}(80: 20$ $[\mathrm{v} / \mathrm{v}])$ was used as substrates. Growth was followed by measuring the optical density at $600 \mathrm{~nm}\left(\mathrm{OD}_{600}\right)$.

\section{Preparation of cell suspensions}

The medium and all buffers were prepared using the anaerobic techniques described [32, 33]. All preparation steps were performed under strictly anaerobic conditions at room temperature in an anaerobic chamber (Coy Laboratory Products, Grass Lake, MI) filled with 95-98\% $\mathrm{N}_{2}$ and $2-5 \% \mathrm{H}_{2}$ as described [30]. A. woodii (DSM 1030) was grown in carbonate buffered medium till late exponential phase, harvested by centrifugation, and washed two times with imidazole buffer $(50 \mathrm{mM}$ imidazole$\mathrm{HCl}, 20 \mathrm{mM} \mathrm{MgSO}$, $20 \mathrm{mM} \mathrm{KCl}, 4 \mathrm{mM}$ DTE, $1 \mathrm{mg} \mathrm{L}^{-1}$ resazurin, $\mathrm{pH}$ 7.0). Cells were resuspended in imidazole buffer and transferred to Hungate tubes. The protein concentration of the cell suspension was determined as described previously [34]. To remove remaining $\mathrm{H}_{2}$ from the Hungate tube, the gas phase of the cell suspension was changed to $\mathrm{N}_{2}$ and the cells were stored on ice until use. For the experiments, the cells were suspended in the same buffer to a concentration of $1 \mathrm{mg} \mathrm{mL}^{-1}$ in 115 $\mathrm{mL}$ glass bottles. The bottles contained a final volume of $10 \mathrm{~mL}$ buffer under an $\mathrm{N}_{2}$ atmosphere and were incubated at $30{ }^{\circ} \mathrm{C}$ in a shaking water bath. Samples for substrate/product determination were taken with a syringe, cells were removed by centrifugation $(15,000 \mathrm{~g}, 2 \mathrm{~min})$, and the supernatant was stored at $-20{ }^{\circ} \mathrm{C}$ until further analysis. For determination of $\mathrm{H}_{2}$, gas samples were taken with a gas tight syringe (Hamilton Bonaduz AG, Bonaduz, Switzerland) and analyzed by gas chromatography.

\section{Closed batch fermentations}

Acetobacterium woodii (DSM 1030) was grown at $30{ }^{\circ} \mathrm{C}$ in $50 \mathrm{~mL}$ phosphate buffered medium in $115-\mathrm{mL}$ glass bottles containing an initial gas phase of $100 \% \mathrm{~N}_{2}$. Samples for substrate/product determination were taken with a syringe and handled as described for the cell suspension experiments.

\section{Determination of hydrogen, formate, and acetate}

For determination of $\mathrm{H}_{2}$, the gas samples were analyzed by gas chromatography on a Clarus 580 GC (Perkin Elmer, Waltham, USA) with a ShinCarbon ST 80/100 column ( $2 \mathrm{~m} \times 0.53 \mathrm{~mm}$, PerkinElmer, Waltham, MA, USA). The samples were injected at $100{ }^{\circ} \mathrm{C}$ with nitrogen as carrier gas with a head pressure of $400 \mathrm{kPa}$ and a split flow of $30 \mathrm{~mL} \mathrm{~min}{ }^{-1}$. The oven was kept at $40{ }^{\circ} \mathrm{C}$ and $\mathrm{H}_{2}$ was determined with a thermal conductivity detector at $100{ }^{\circ} \mathrm{C}$. The peak areas were proportional to the concentration of $\mathrm{H}_{2}$ and calibrated with standard curves.

The concentration of formate was determined with an enzymatic assay using the formate dehydrogenase from Candida boidinii (Sigma-Aldrich, Munich, Germany). The assay contained in addition to the sample $1 \mathrm{U}$ of enzyme in $50 \mathrm{mM}$ potassium phosphate buffer $(\mathrm{pH} 7.5)$ and $2 \mathrm{mM} \mathrm{NAD}^{+}$. Formation of NADH was measured photometrically at $340 \mathrm{~nm}$. Sodium formate was used for preparation of standard curves.

Acetate was measured using a commercially available enzymatic assay kit from R-Biopharm (Darmstadt, Germany).

\section{Chemicals}

All chemicals were supplied by Sigma-Aldrich Chemie $\mathrm{GmbH}$ (Munich, Germany) and Carl Roth $\mathrm{GmbH} \& \mathrm{Co}$ KG (Karlsruhe, Germany). All gases were supplied by Praxair (Düsseldorf, Germany).

\section{Authors' contributions}

VM and KS designed and supervised the research, analyzed the data, and wrote the manuscript. PK performed the experiments and analyzed the data. All authors read and approved the final manuscript.

\section{Acknowledgements}

This project has received funding from the European Research Council (ERC) under the European Union's Horizon 2020 research and innovation programme (Grant Agreement No 741791).

\section{Competing interests}

The authors declare that they have no competing interests.

\section{Availability of data and materials}

All data generated or analyzed during this study are included in this published article.

Consent for publication Not applicable.

Ethics approval and consent to participate Not applicable.

\section{Publisher's Note}

Springer Nature remains neutral with regard to jurisdictional claims in published maps and institutional affiliations.

Received: 27 January 2018 Accepted: 14 March 2018 Published online: 02 April 2018

References

1. Schlapbach L, Zuttel A. Hydrogen-storage materials for mobile applications. Nature. 2001;414:353-8. 
2. Das D, Veziroglu TN. Advances in biological hydrogen production processes. Int J Hydrog Energy. 2008;33:6046-57.

3. Manish S, Banerjee R. Comparison of biohydrogen production processes. Int J Hydrog Energy. 2008;33:279-86.

4. Rittmann S, Herwig C. A comprehensive and quantitative review of dark fermentative biohydrogen production. Microb Cell Fact. 2012;11:115.

5. Rittmann SK, Lee HS, Lim JK, Kim TW, Lee JH, Kang SG. One-carbon substrate-based biohydrogen production: microbes, mechanism, and productivity. Biotechnol Adv. 2015;33:165-77.

6. Jhong HR, Ma SC, Kenis PJA. Electrochemical conversion of $\mathrm{CO}_{2}$ to useful chemicals: current status, remaining challenges, and future opportunities. Curr Opin Chem Eng. 2013;2:191-9.

7. Agarwal AS, Zhai Y, Hill D, Sridhar N. The electrochemical reduction of carbon dioxide to formate/formic acid: engineering and economic feasibility. Chemsuschem. 2011;4:1301-10.

8. Böhm R, Sauter M, Böck A. Nucleotide sequence and expression of an operon in Escherichia coli coding for formate hydrogen lyase components. Mol Microbiol. 1990;4:231-43.

9. Sawers RG. Formate and its role in hydrogen production in Escherichia coli. Biochem Soc Trans. 2005:33:42-6.

10. Calusinska M, Happe T, Joris B, Wilmotte A. The surprising diversity of clostridial hydrogenases: a comparative genomic perspective. Microbiology. 2010;156:1575-88

11. Bae SS, Kim YJ, Yang SH, Lim JK, Jeon JH, Lee HS, Kang SG, Kim SJ, Lee JH. Thermococcus onnurineus sp nov., a hyperthermophilic Archaeon isolated from a deep-sea hydrothermal vent area at the PACMANUS field. J Microbiol Biotechnol. 2006;16:1826-31.

12. Lim JK, Bae SS, Kim TW, Lee JH, Lee HS, Kang SG. Thermodynamics of formate-oxidizing metabolism and implications for $\mathrm{H}_{2}$ production. Appl Environ Microbiol. 2012;78:7393-7.

13. Lim JK, Mayer F, Kang SG, Müller V. Energy conservation by oxidation of formate to carbon dioxide and hydrogen via a sodium ion current in a hyperthermophilic archaeon. Proc Natl Acad Sci USA. 2014;111:11497-502.

14. Kim YJ, Lee HS, Kim ES, Bae SS, Lim JK, Matsumi R, Lebedinsky AV, Sokolova TG, Kozhevnikova DA, Cha SS, et al. Formate-driven growth coupled with $\mathrm{H}_{2}$ production. Nature. 2010;467:352-5.

15. Schuchmann K, Müller V. Direct and reversible hydrogenation of $\mathrm{CO}_{2}$ to formate by a bacterial carbon dioxide reductase. Science. 2013;342:1382-5.

16. Fujita E, Muckerman JT, Himeda Y. Interconversion of $\mathrm{CO}_{2}$ and formic acid by bio-inspired Ir complexes with pendent bases. Biochim Biophys Acta. 2013;1827:1031-8.

17. Mellmann $D$, Sponholz $P$, Junge $H$, Beller M. Formic acid as a hydrogen storage material-development of homogeneous catalysts for selective hydrogen release. Chem Soc Rev. 2016;45:3954-88.

18. Enthaler S, von Langermann J, Schmidt T. Carbon dioxide and formic acid - the couple for environmental-friendly hydrogen storage? Energy Environ Sci. 2010:3:1207-17.
19. Balch WE, Schoberth S, Tanner RS, Wolfe RS. Acetobacterium, a new genus of hydrogen-oxidizing, carbon dioxide-reducing, anaerobic bacteria. Int J Syst Bacteriol. 1977;27:355-61.

20. Schuchmann K, Müller V. Autotrophy at the thermodynamic limit of life: a model for energy conservation in acetogenic bacteria. Nat Rev Microbiol. 2014;12:809-21.

21. Wood HG, Ljungdahl LG. Autotrophic character of the acetogenic bacteria. In: Shively JM, Barton LL, editors. Variations in autotrophic life. San Diego: Academic press; 1991. p. 201-50.

22. Poehlein $A$, Schmidt S, Kaster A-K, Goenrich M, Vollmers J, Thürmer A, Bertsch J, Schuchmann K, Voigt B, Hecker M, et al. An ancient pathway combining carbon dioxide fixation with the generation and utilization of a sodium ion gradient for ATP synthesis. PLoS ONE. 2012;7:e33439.

23. Lu W, Du J, Wacker T, Gerbig-Smentek E, Andrade SL, Einsle O. pHdependent gating in a FocA formate channel. Science. 2011;332:352-4.

24. Wang Y, Huang Y, Wang J, Cheng C, Huang W, Lu P, Xu YN, Wang P, Yan $\mathrm{N}$, Shi Y. Structure of the formate transporter FocA reveals a pentameric aquaporin-like channel. Nature. 2009;462:467-72.

25. Thauer RK, Jungermann K, Decker K. Energy conservation in chemotrophic anaerobic bacteria. Bacteriol Rev. 1977:41:100-80.

26. Seol E, Kim S, Raj SM, Park S. Comparison of hydrogen-production capability of four different Enterobacteriaceae strains under growing and non-growing conditions. Int J Hydrog Energy. 2008;33:5169-75.

27. Yoshida A, Nishimura T, Kawaguchi H, Inui M, Yukawa H. Enhanced hydrogen production from formic acid by formate hydrogen lyase-overexpressing Escherichia coli strains. Appl Environ Microbiol. 2005;71:6762-8

28. Yoshida A, Nishimura T, Kawaguchi H, Inui M, Yukawa H. Efficient induction of formate hydrogen lyase of aerobically grown Escherichia coli in a three-step biohydrogen production process. Appl Microbiol Biotechnol. 2007;74:754-60.

29. Seol E, Manimaran A, Jang Y, Kim S, Oh YK, Park S. Sustained hydrogen production from formate using immobilized recombinant Escherichia coli SH5. Int J Hydrog Energy. 2011:36:8681-6.

30. Heise R, Müller V, Gottschalk G. Presence of a sodium-translocating ATPase in membrane vesicles of the homoacetogenic bacterium Acetobacterium woodii. Eur J Biochem. 1992;206:553-7.

31. Imkamp F, Müller V. Chemiosmotic energy conservation with $\mathrm{Na}^{+}$as the coupling ion during hydrogen-dependent caffeate reduction by Acetobacterium woodii. J Bacteriol. 2002;184:1947-51.

32. Bryant MP. Commentary on the Hungate technique for culture of anaerobic bacteria. Am J Clin Nutr. 1972;25:1324-8.

33. Hungate RE. A roll tube method for cultivation of strict anaerobes. In: Norris JR, Ribbons DW, editors. Methods in microbiology. New York: Academic Press; 1969. p. 117-32.

34. Schmidt K, Liaaen-Jensen S, Schlegel HG. Die Carotinoide der Thiorhodaceae. Arch Mikrobiol. 1963:46:117-26.

\section{Submit your next manuscript to BioMed Central and we will help you at every step:}

- We accept pre-submission inquiries

- Our selector tool helps you to find the most relevant journal

- We provide round the clock customer support

- Convenient online submission

- Thorough peer review

- Inclusion in PubMed and all major indexing services

- Maximum visibility for your research

Submit your manuscript at www.biomedcentral.com/submit
BioMed Central 